CDD: $551.480981 / 5$

\title{
A NOTE ON THE SEASONALLY SHIFTING ZONE OF HIGH PRIMARY PRODUCTION IN THE BAY OF MARAJÓ, PARÁ, BRAZIL, 1983-1984 ${ }^{1}$
}

\author{
H.O. Schwassmann 2 \\ R.B. Barthem ${ }^{3}$ \\ M.L. Carvalho 3
}

\begin{abstract}
To understand the hydrological and limnological conditions during the annual regime of high and low river flow, as well as the action of the tides, a series of 18 collecting trips were conducted in monthly and bimonthly intervals across the Bay of Marajó during the years 1983-1985. The Tocantins River provides more than $80 \%$ of the inflow into this bay and shows a much greater difference in water volume flow between high and low water season than the Amazon. The annual displacement of brackish water influence is thus more extensive Marajó Bay than in the Amazon estuary. During the dry season of low river discharge (September-December), traces of seawater are found to penetrate up to $90 \mathrm{~km}$ upriver in the Guamá River. The high degree of turbidity of inner estuarine waters impedes light penetration and results in the near absence of primary production in spite of ample nutrients. Where these turbid river waters mix with brackish estuarine waters of 2 to $4 \% 0$ salinity, flocculation and subsequent sedimentation causes visibility to increase from a few to sometimes $200 \mathrm{~cm}$. The water in this zone assumes a bright green color due to phytoplankton. About $90 \%$ of the biomass consists of a polyhalobic diatom species, Coscinodiscus. Concomitant great reductions in silica and other nutrient concentrations are noted. During low river flow (September to December), this high production zone is located in the central part of Marajó Bay, whereas it lies outside of the bay over the continental shelf during high river discharge (February to April).
\end{abstract}

Key Words: Limnology, Amazon Estuary, Tidal Rivers, Estuary Hydrodynamics, Phytoplankton.

\begin{abstract}
RESUMO - Uma série de 18 travessias, em intervalos mensais ou bimensais, na baía do Marajó nos anos 1983-1985, a fim de medir os parâmetros físico-químicos e coletar plâncton, contribuiu para nosso conhecimento das condições hidrocinéticas e limnológicas durante o ciclo anual de vazão alta e baixa dos rios e das marés. Devido à diferença de vazão entre a cheia e a seca no rio Tocantins ser maior que no rio Amazonas, a entrada de água salobra na baia do Marajó é mais extensa que na foz do rio Amazonas. No período de seca há indícios de água marinha até $90 \mathrm{~km}$ na montante no rio Guamá. A turbidez das águas do estuário interno impede a penetração de luz, resultando em falta de produção primária, apesar dos amplos nutrientes. Na zona de encontro das águas túrbidas com as salobras (com salinidade de 2 a $4 \%$ ), a matéria em suspensão agrega-se em flocos maiores que se sedimentam, o que aumenta a claridade da água (visibilidade de até $200 \mathrm{~cm}$ ). A água nesta zona torna-se verde devido à produção de fitoplâcton, sendo que $90 \%$ dessa biomassa é constituída da diatomácea marinha Coscinodiscus. Coincidentemente, nota-se grande diminuição no teor de sílica e de outros nutrientes. Durante o periodo de vazão baixa, a zona de alta produtividade se encontra fora da baía do Marajó, nas águas de plataforma continental.
\end{abstract}

Palavras-chave: Limnology, Amazon Estuary, Tidal Rivers, Estuary Hydrodynamics, Phytoplankton.

\section{Introduction}

Sometimes considered the southern arm of the Amazon River estuary, the Bay of Marajó lies between $0020^{\prime} \mathrm{S}-1^{\circ} 45^{\prime} \mathrm{S}$ and $47^{\circ} 50^{\prime} \mathrm{W}-48^{\circ} 50^{\prime} \mathrm{W}$. This bay is the estuary of the Tocantins River and some other smaller rivers and streams.

1 In memory of Dr. Walter Alberto Egler, Botanist and Director of the Emílio Goeldi Museum until his tragic death in August, 1961.

2 University of Florida, Department of Zoology, Gainesville, Florida, U.S.A. 32611.

3 CNPq/Museu Paraense Emílio Goeldi, Depto. de Zoologia. 
Two river pairs, the Capim-Guamá and the Acará-Mojú, join Marajó Bay by means of the small Bay of Guajará at the large por city of Belém (Figure 1). Deep channels at the southwestern corner of Marajó Island connect the inward continuation of Marajó Bay, the Rio Pará, with the Amazon River. These channels, known as the straits of Brêves are the principal navigation route to the middle and upper Amazon and some net flow of amazon water into the Pará River takes place. Primary production in Amazonian rivers is limited either by the low nutrient content of black and clearwater streams, or by the high degree of turbidity, impeding light penetration in the white water streams (Fittkau et al.1975). In the estuary the amount of suspended matter and resulting turbidity are increased greatly due to the tides, which cause not only constantly changing directions of flow but also volume transport and speeds greatly exceeding those of the river's net discharge and current. We studied flow dynamics and salinity changes in the Bay of Marajó over more than a seasonal cycle in continuation of an earlier preliminary survey of the inner Amazon estuary in 1961 (Egler \& Schwassmann 1962). We were able to observe the szasonal longitudinal displacement of a zone of high phytopankton production.

\section{Methods}

From early August 1983 through April 1985 eighteen sampling trips were made in monthly to bimonthly intervals through the Bay of Marajó. These trips lasted from one to five days each and were either transects across the bay or were conducted in a longitudinal direction. Occasional vertical transects tested for'vertical gradients. Eleven trips were realized during the low-water season ("verão") when river discharge is low (Figure 2), while seven trips were made during the high water season ("inverno") (Figure 3). Early in the study fishing boats were rented; later, a two-ton, ten-meter-long, diesel-powered fishing boat was converted for our use. Conventional limnological apparatus consisted of a Fisher temperature-compensated conductivity/salinity bridge, a Corning $3 \mathrm{D} \mathrm{pH}$ meter, a YSI 51 B dissolved oxygen/temperature meter, a Sonar DC 240 depth recorder, a B\&L Spectronic-mini 20 spectrophotometer with nephelometer attachment, Spectrokits for chemical analyses, a calibrated Clarke-Bumpus plankton sampler with nets of nos. 10 and 20 bolting cloth, and diverse small items. Horizontal tows at one - five - and ten-meter depth were made, lasting one, three, or five minutes. Samples were preserved in buffered formalin and a Sedgwick-Rafter cell was employed for quantitative estimation.

\section{Physical definition of the study area}

For the purpose of this study, we define the Bay of Marajó as the estuarine area from the entrance of the Tocantins mouthbay to the $60-\mathrm{km}$-long line connecting the Cape of Maguarí to the small island of Tijoca (Figure 1). This limited part of a larger bay is $200 \mathrm{~km}$ long; its area, excluding all smaller tributary estuaries, is $6,620 \mathrm{~km}^{2}$ at an average mean low water depth of $7.0 \mathrm{~m}$, yielding a low-tide volume of $46.3 \mathrm{~km}^{3}$. At the head of Marajó Bay the Tocantins mouthbay is joined by the "Rio Pará". This $120 \mathrm{~km}$ long embayment forms the southern border of Marajó Island and originates from the straits of Breves. It is here that the Amazon communicates through a labyrinth of narrow and deep channels ("furos") with the Rio Pará, while the most southern of these channels bring water from another also $120 \mathrm{~km}$ long westward extension of the embayment, the bays of Melgaço, Portel, Pacajaí, and Caxiuná. Many small rivers of unknown discharge empty into this system and there are also small connections to the Amazon in the north. The entire southern bay system is approximately as long as the inner bay of the Amazon estuary when the latter is taken to extend from the Xingu mouthbay around the western and northern coast of the island to the shallows at Marajó's northeast cor- 
ner where the encounter of Amazon waters and Marajó Bay outflow was found to take place (Egler \& Schwassmann 1962) (Figure 1).

\section{Some hidrological features and their seasonal variation.}

The Araguaia-Tocantins River drainage has a total area of about $0.7 \times 10^{6} \mathrm{~km}^{2}$. We calculate that the average annual discharge is approximately $15,000 \mathrm{~m}^{3} \mathrm{x} \mathrm{sec}^{-1}$, although an earlier estimate by Oltman (1968) was $10,000 \mathrm{~m}^{3} \mathrm{x} \mathrm{sec}^{-1}$. Averaging many years of data from diverse sources yields a mean high-water season discharge of $36,000 \mathrm{~m}^{3} \mathrm{x} \mathrm{sec}-1$ (February - April), and a mean low water discharge of $5,000 \mathrm{~m}^{3} \mathrm{x} \mathrm{sec}^{-1}$ (November). Heavy flooding in 1974 and 1980 caused maximal discharge levels of $68,000 \mathrm{~m}^{3} \mathrm{x} \mathrm{sec}^{-1}$. Based on the calculated values, the Tocantins contributes about $80 \%$ of the freshwater input into the lower estuarine bay. Near the city of Belém two river pairs enter the Bay of Marajó by means of their own estuary, the Bay of Guajará; separating the two bays are several alluvial islands. These rivers are the Capim-Guamá of $51,000 \mathrm{~km}^{2}$ catchment area, and the Acará-Mojú of $30,000 \mathrm{~km}^{2}$ catchment area. The annual flow regime of the Capim-Guamá has been studied and ranges from an average high of $2,000 \mathrm{~m}^{3} \mathrm{x} \mathrm{sec}^{-1}$ in the wet season, peaking in February-March, to a low of $500 \mathrm{~m}^{3} \mathrm{x} \mathrm{sec}^{-1}$ in December (Egler \& Schwassmann 1962 and this study). Based on drainage area. the discharge of the AcaráMojú should be about $3 / 5$ of the Guamá-river system.

We calculate a mean residence time for Tocantins water in the Bay of Marajó of 36 days, ranging from 15 days during high river discharge to 107 days during low river flow in the dry season.

The semidiurnal and symmetrical tides enter into the inner estuarine basin and rivers where substantial bottom and lateral friction cause an increase in amplitude. Maximal tidal differences of nearly four meters during the spring equinox alternate with mininum level changes of around one meter during increasing and decreasing phases of the moon. Due to the great length of the bay, a six-hour delay is noted before the tidal wave reaches the mouth of the Tocantins from the bay entrance. As a result, high and low tide levels are present at the same moment at the different ends of the Bay of Marajó. Egler Schwassmann (1962) found that flood tidal periods are slightly shorter than ebb periods, 5.1-5.3 hours versus 6.9-7.6 hours. Current speeds and calculated momentary discharge values were about equal during both phases and depended on the tidal amplitudes. Current speeds of up to $1.7 \mathrm{~m} \mathrm{x} \mathrm{sec}^{-1}$ were recorded in both directions during a tidal cycle of 3.6 meter amplitude. At certain places in the inner estuary where shallows and funnel-like restrictions are located, the incoming tidal wave is known to travel upstream as a bore. In the Amazon estuary and in rivers of the Marajó Bay estuary, such "pororoca" has been reported from many places, and a detailed account of it in the Guamá River near São Domingos do Capim was given by Martius on pages 956-961 of Spix \& Martius (1831).

Marajó Bay is a well-mixed estuary without persisting salinity differences between surface and bottom and the net flow is toward the ocean at all depths. Lateral variations in salinities were noted, especially in small seaward facing inlets of the outer bay and in the many small rivers draining the eastern part of Marajó Island. These rivers are without any discharge of their own from October to December and merely fill with bay water, which can remain in their upper courses long after the large bay has freshened substantially from the early wet season floods of the Araguaia-Tocantins. The original upper tidal limit of the Tocantins is not know to us since the hydroelectric power plant dam was already nearing completion during our study. Tidal level changes seem to reach to between Baião and the dam at Tucuruí, about $200 \mathrm{~km}$ from where the Tocantins mouthbay enters the Bay of Marajó; current reversals due to tide level changes can be noted in the mouthbay. For the Guamá River we found the tidal river limit to reach to Capitão 
Poço, a distance of $205 \mathrm{~km}$ from Belém, while the tidally induced current reversal was seen above São Miguel do Guamá, about $135 \mathrm{~km}$ upstream of Belém. During the dry season brackish water reaches to the mouthbay of the Tocantins; it was noted $90 \mathrm{~km}$ upriver from Belém in the Guamá.

We can define a transition zone as the stretch of intensive mixing of fresh and seawater; an arbitrary range of salinities from 0.6 to $6.0 \%$ can be used as upper and lower limits. During the end of the dry season this zone extends from about $50 \mathrm{~km}$ inside the Guamá River, to a line across the bay at the level of Soure on Marajó Island (Figure 1). The remaining seaward portion of the bay and the open water over part of the continental shelf would then have to be considered as part of the estuary, limited by salinities from 6 to about $30 \%$. With seasonally increasing river flow the dynamic boundaries shift seaward and the upper tidal limit displaces downstream while brackish water penetrates to the level of Soure, about $75 \mathrm{~km}$ downstream while brackish water penetrates to the level of Soure, about $75 \mathrm{~km}$ downstream from Belém. In the wet season, the transition zone moves to the outer half of Marajó Bay and over the continental shelf, while the inner half of the bay remains under the sole domain of pure river water.

\section{Sediment load and phytoplankton production}

All rivers that discharge into the Bay of Marajó are known to carry clear water in their upper courses. However, the waters inside the bay and in the lower river parts downstream of the head of the tide are extremely turbid from a sediment load exceeding that of the Amazon River. This sediment load comes from resuspension of older alluvial deposits of originally Andean piedmont origin, and there is an upstream-directed transport of resuspended particles under the action of tidal currents in the estuaries of these rivers and in Marajó Bay (Egler \& Schwassmann 1962). Where these sediment-laden river waters meet with brackish bay water of a certain salinity, usually between 2 and $4 \%$ ( $>5.0 \mathrm{mS}$ conductivity), flocculation occurs and larger particles from which rapidly settle to the bottom. We measured sudden increases in visibility in these flocculationsedimentation zones from $20 \mathrm{~cm}$ up to $200 \mathrm{~cm}$. In this area the water's color changed suddenly from the usual yellow-brown to a striking green color caused by a phytoplankton bloom. About $90 \%$ of the plankton consisted of a polyhalobic diatom (Coscinodiscus) in such concentrations that one-minute net hauls at slow speeds usually clogged the plankton net. Densities of $>1,000$ cells per ml were common. Comparing samples from the turbid brown water with clear high-production water showed a significant decrease in nutrient content. Most striking was the drop of $\mathrm{SiO}_{2}$ from a range of 5.0 to $7.0 \mathrm{mg} / 1$ in turbid river water of the upper bay to values below $1.0 \mathrm{mg} / 1 \mathrm{Si}_{2}$ in the productive zone.

From October to December 1983, when river flow was low, we located this zone of high primary production in the central bay at about the level of Mosqueiro Island (Figure 4). At the peak of the wet season, the nearly seven fold increase in river flow causes this high production zone to move outside of the bay in the outer estuary over the continental shelf. Although our 1983-84 cruises did not cover that area of the outer estuary, we located the green high-production waters in our earlier work in April of 1961 (Egler \& Schwassmann 1962). This region is indicated on the map (Figure 4).

\section{Discussion and conclusion}

The Tocantins River provides more than $80 \%$ of the freshwater input into Marajó Bay during the rainy season, while its contribution during the dry period is estimated to bem somewhat less, about $70 \%$ of the total inflow. From the dry to the rainy season, 
there is as increase of six to seven times in total water volume flowing into the Bay of Marajó, This results in a very extensive displacement of the transition zone, the area of major mixing of river with sea water. The displacement of this zone is probably much more estensive than it is in the Amazon estuary, where the increase in discharge during the high water period is a mere two to three times that of the dry period river flow. The contrasting high-low water discharge ratios of the two river systems are due to the different extent and geographic location of their respective drainage basins. The AraguaiaTocantins and smaller Marajó Bay tributaries drain a smaller area of similar annual rainfall distribution where a wet season occurs mainly from December to May, while the much larger drainage basins of the Amazon and its tributaries cover areas of the differing annual rainfall patterns south and north of the equator.

Few studies have attempted to investigate flow pattern and salinity changes in the inner estuaries of the Amazon and the Bay of Marajó (Egler \& Schwassmann 1962; Ryther et al. 1967; Gibbs 1970). Ryther et al. (1967) report the existence of a salinity wedge in Marajó Bay as well as salinities of $14 \% 50$ miles inside the bay, conditions which we could not verify in this or in our earlier study. Milliman et al. (1975) investigated diatom production and silica levels over the outer shelf and cited some representative silica and other nutrient concentrations for pure river, bay, and shelf waters, to which our measured values correspond.

Earlier work concentrated on primary production in outer shelf waters and implicated the Amazon River as the world's largest supplier of silica to the oceans summarized by (Milliman et al. 1975). In this study, we found a zone of high diatom production inside Marajó Bay and followed its annual shift in location caused by differences in river flow. High diatom production in the inner estuary is caused by the mixing of turbid river water with brackish water of 2 to $4 \%$ salinity which results in flocculation of suspended matter into larger particles; these larger aggregates settle rapidly, permitting light penetration and subsequent photosynthesis.

A recent study utilizing satellite imagery demonstrates zones of high chlorophyll concentrations over the continental shelf suring the Amazon's high discharge season with a wedge penetrating into the Bay of Marajó along the island's western shore (Curtin 1986 a,b; Curtin \& Legeckis 1986).

\section{Acknowledgements}

We thanks Drs. F.G. Nordlie, J.S. Lourenço, and F.C. Novaes for support and encouragement. The Zoology Department, University of Florida, provided most of the equipment and supplies, while the Goeldi Museum at Belém provided logistic and financial support through CNPq fellowships and grants. H.O.S. was on sabbatical leave from the University of Florida.

\section{References}

CURTIN, T. B. Physical observations in the plume region of the Amazon River during peak discharge -2 . Water masses. Contin. Shelf Res., 6:53-71.

CURTIN, T. B. Physical observations in the plume region of the Amazon River during peak discharge - 3. Currents. Contin. Shelf Res., 6:73-86.

CURTIN, T. B. \& LEGECKIS, R.V. 1986. Physical observations in the plume region of the Amazon River during peak discharge -1 . Surface variability. Contin. Shelf Res., 6:31-51. 
EGLER, W.A. \& SCHWASSMANN, H.O. 1962. Limnological studies in the Amazon estuary. Publ. Avulsas Mus. Emilio Goeldi, Belém, (1): 2-25.

FITTKAU, E. J.; IRMLER, U.; JUNK, W.J.; REISS, F. \& SCHMIDT, G. W. 1975. Productivity, biomass, and population dynamics in Amazonian water bodies. IN: GOLLEY, F. B. \& MEDINA, E. (eds.) Tropical ecological systems. Trends in Terres trial and aquatic research. New York. p. 289-311.

GIBS, R.J. 1970. Circulation in the Amazon River estuary and adjacent Atlantic Ocean. J. Marine Res., 28:113-123.

MILLIMAN, J. D.; USMMERHAYES, C.P. \& BARETTO, H.T. 1975. Oceanography and suspended matter fo the Amazon River. J. Sedim. Petrol., 45:189-206.

RYTHER, J.H.; MENZEL, D.W. \& CORWIN, N. 1967. Influence of the Amazon River outflow on the ecology of the western tropical Atlantic. Hydrography and nutrient chemistry. J. Marine Res., 25:69-83.

SPIX, J. B. \& MARTIUS, C.F.P. 1831. Reise in Brasilien auf Befehl Sr. Majestät Maximilian Joseph 1. München. V. 3, p. - 1-56, 887-1388, 1-40. 


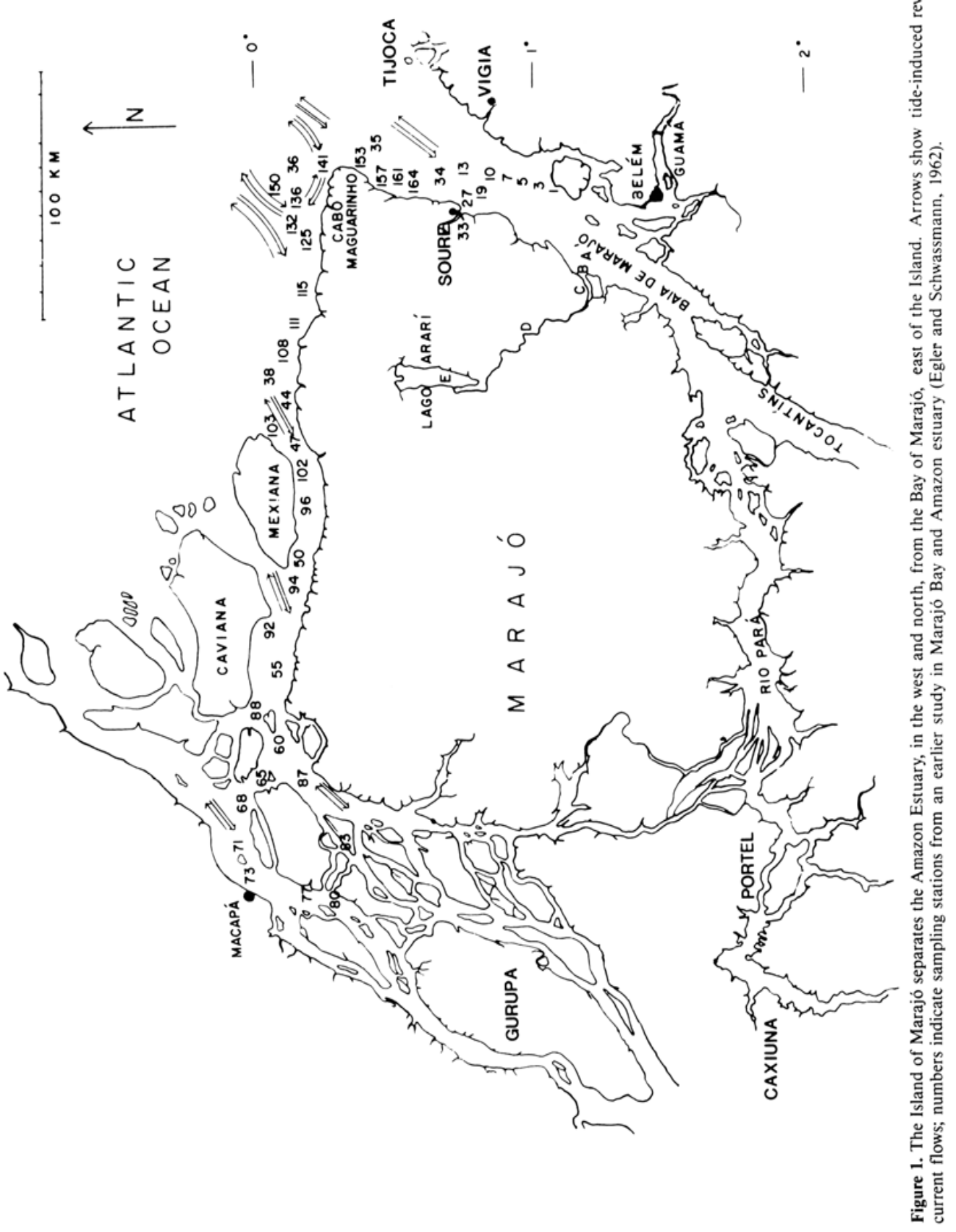




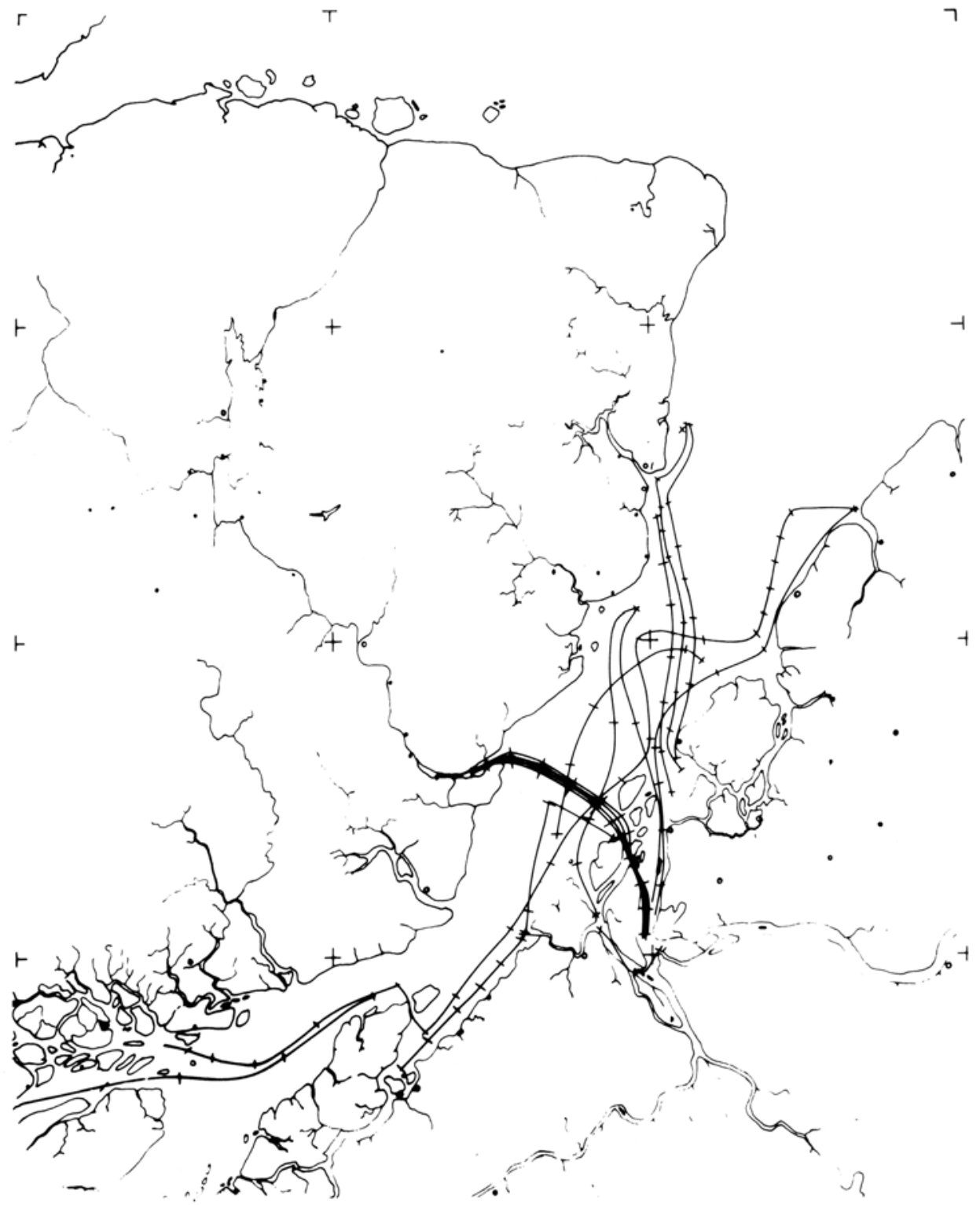

Figure 2. Sampling trips and collecting stations in Marajó Bay during the low river flow season ("versão"), 6 August 1983 - 4 December 1983 and 5 July 1984 - 9 Januar:' 1985. 


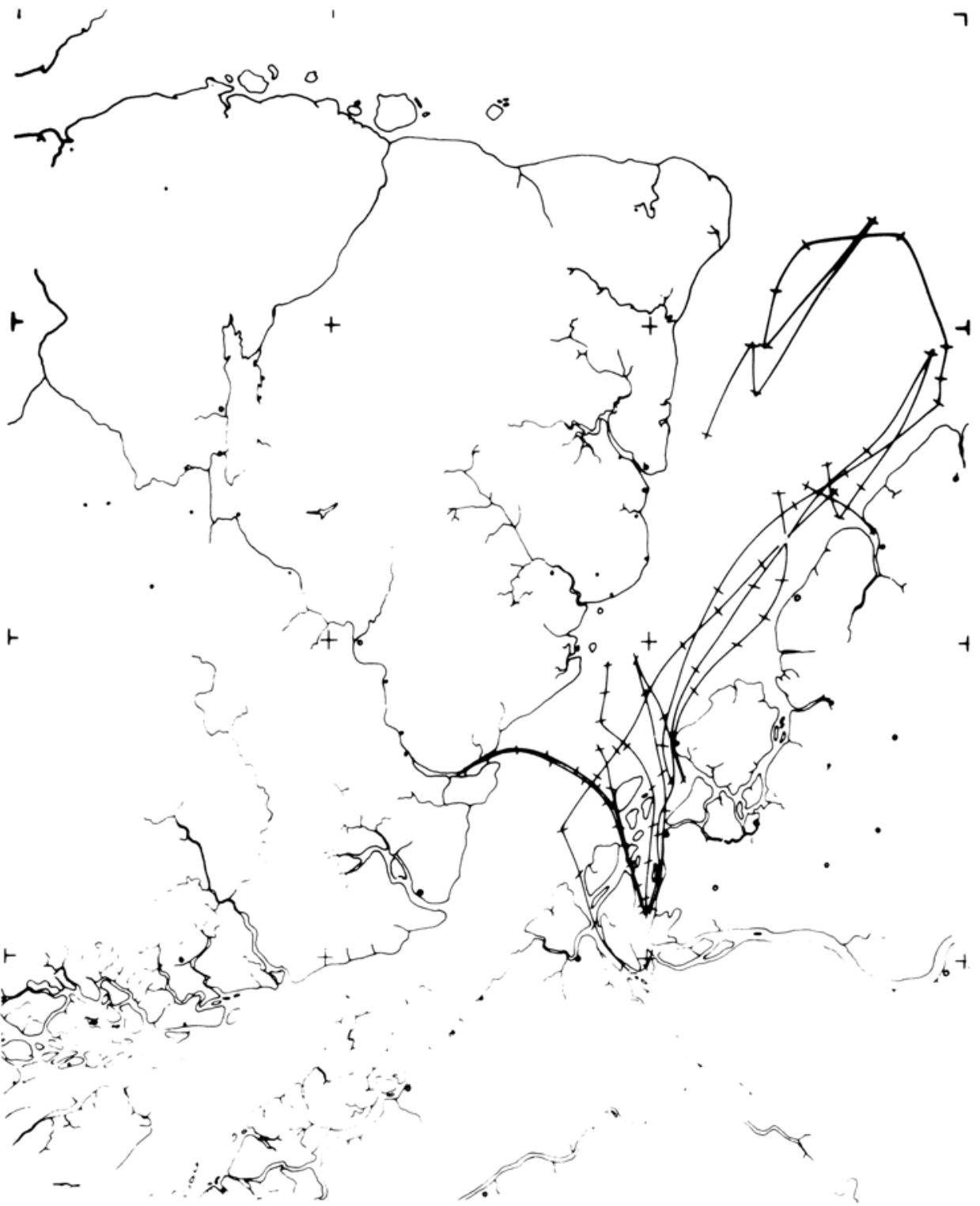

Figure 3. Sampling trips and collection sites in Marajó Bay during high discharge season ("inverno"), 17 February 1984 - 11 June 1984 and 9 February 1985 - 4 April 1985. 


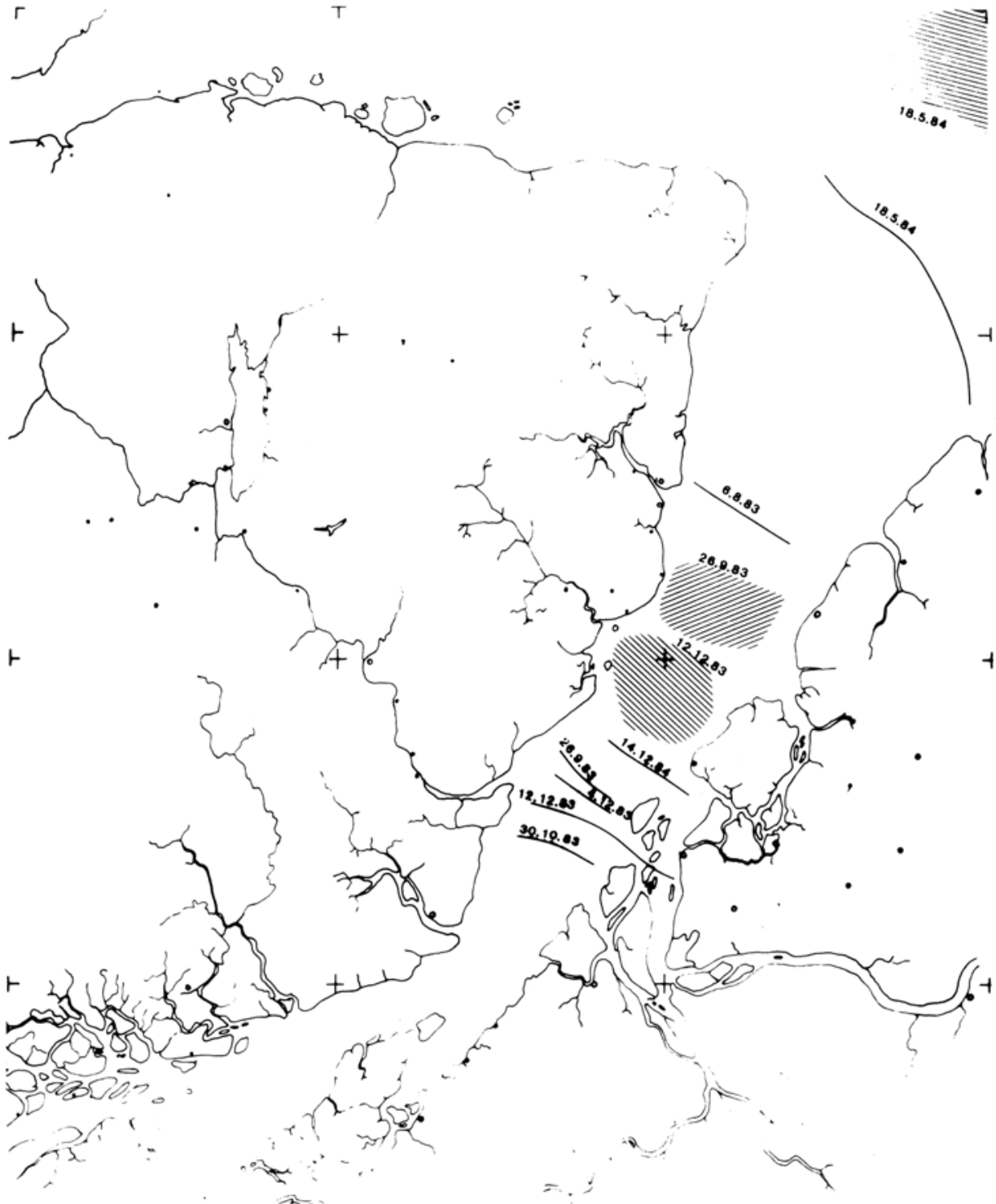

Figure 4. Mapped locations of the zone of high diatom production, at three differnt dates of the annual cycle, indicated by shading. Dated lines show corresponding $2.5 \%$ isohalines. 